\title{
Does Public Deficit Mean Inflation? A Reflection on the Kaleckian and Minskian Tradition
}

\author{
Narciso Tuñez-Area* \\ This paper analyses the determination of prices within a Kaleckian and Minskian \\ framework. In the Minskian model, public deficit generates mark-up infla- \\ tion, a result that resembles Neo-Keynesian models of growth. In the Kaleckian \\ model, an increase in aggregate demand is not absorbed by inflated prices but \\ by a higher utilisation of capacity. This paper discusses issues at the core of Post- \\ Keynesian thought. \\ JEL classification: EI2 \\ Keywords: Kalecki, Minsky, public deficit, inflation, mark-up, Post-Keynesian \\ economics
}

Minsky's determination of prices led him to the conclusion that a higher level of investment is absorbed by higher prices instead of an increase in the utilisation of capacity. The model resembles the Neo-Keynesian models of Kaldor and Robinson, which assume that the rate of utilisation of capacity is given in the long run. The consequence of assuming no excess capacity is that a higher share of investment is always associated with a higher share of profit, due to a higher mark-up.

Minsky's theory represents what Lavoie (1992) calls "an inflationist theory of growth", in which the economy moves along the wage-profit frontier, therefore the paradox of cost disappears (Rowthorn 198I). Along the wage-profit frontier there is a negative relationship between the rate of profit and the real wage, which is what Neo-Ricardian theorists advocate. This result denies the possibility of wage-led growth where higher wage costs lead to higher capacity utilisation, rate of profit and accumulation. The paradox of cost prevails.

* University of Greenwich. I would like to thank Dr. Iago Santos Castroviejo for his constant, valuable and unconditional help. Unfortunately, mistakes are all mine.

Correspondence address:

Narciso Tuñez-Area, University of Greenwich, Business School, Park Row, Greenwich, London SEıo 9LS, UK, e-mail: tni8@gre.ac.uk

Received 16 Feb 2005, accepted 09 Jan 2006

(C) InTERVEntion. Journal of Economics, Vol. 3 (2006), No. 1, pp. 151-167 
This striking feature of Kaleckian models is non-existent in Minsky's models. According to Minsky, expansionary fiscal policy as any increase of aggregate demand will be inflationary (Minsky 1986). In contrast, Kalecki argues that public deficit increases national savings, aggregate profits and the accumulation of productive capacity, which has a positive correlation with employment growth (Rowthorn 1995, Glyn 1998). That is precisely what happened from 1992 onwards in the US, UK and Canada, which experienced high rates of productive capacity growth, employment and surprisingly a declining inflation (Arestis/Sawyer 2003).

The objectives of this paper are as follows: first, to analyse the determination of prices in a Post-Keynesian and Neo-Keynesian framework. Secondly, to resolve a certain apparent confusion between Post-Keynesian and Minskian price formation. This confusion manifests itself in statements like the following:

„However it is very useful to briefly examine Hyman Minsky’s views on price formation in order to provide the background to the Post-Keynesian approach to inflation or determination of prices at the macro-level« (Wray 2000: II).

On the contrary it will be argued that Minsky's price determination is not Post-Keynesian. Finally this paper stresses the causal complexity in the determination of prices and the importance of capital accumulation and utilisation of capacity along with the public deficit and monetary policy to understand it.

The paper will be structured as follows: the first and second part will give a brief summary of the Neo-Keynesian and the Post-Keynesian model, respectively. In the third part the Minskian price determination is analysed within a two-sector model. Starting off from the same equations as Minsky, the fourth section uses these equations to determine output and employment instead of the price level. Finally the government sector is included in the fifth section.

\section{Neo-Keynesian Theory of Inflation}

Neo-Keynesian theories of inflation were first developed by Kaldor and Robinson. The main feature of these models is that the rate of utilisation of capacity is fixed at its full capacity value. We will assume a one-sector model economy in which investment is given in real terms, $w$ are the wages paid per unit of labour, $N$ is employment, $p$ is the price-level, $Q$ is the real output and $I$ is the autonomous investment. In equilibrium (see Appendix I): ${ }^{I}$

$$
p \cdot Q=w \cdot N+p \cdot I \quad(\text { I.AI })
$$

I Assumptions: no overhead labour; capitalists do not consume. 


\section{I.I Profit Share and Utilisation of Capacity}

There are two ways to express the profit share, which are shown in equations three and five of Appendix I (with $\Pi$ as aggregate profits, $Q_{M}$ as output at full capacity, $u$ as utilisation of capacity and $\sigma$ as mark-up).

$$
\begin{gathered}
\Pi=\frac{I}{u \cdot Q_{M}}=\frac{I}{Q} \quad \text { (3.AI) } \\
\Pi=\frac{\sigma}{1+\sigma} \text { (5.AI) }
\end{gathered}
$$

Both have to be equal.

Lavoie argues that without overhead labour,

"the share of profits could not go up when investment went up, unless the markup changed, and the mark-up could only change automatically in situations of full utilisation of capacity." (Lavoie 1992: 266)

He seems to say that without overhead labour, one has to assume full capacity utilisation for the share of profits to increase when investment goes up. In contrast, this article argues that the investment-to-output-ratio (equation 3.Ar for a given mark-up) remains constant when investment goes up due to the increase in the utilisation of capacity. Changes in the investment-to-output-ratio could only come about through changes in the mark-up. Lavoie seems to say that the assumption of no overhead labour costs plays a major role in the assumption of full capacity utilisation for the share of profits to adjust to the increased investment ratio. However that is not the case, as the investment-to-output-ratio remains constant for a determined mark-up as long as the utilisation of capacity is not at its maximum level.

From Appendix I we know that the utilisation of capacity is:

$$
u=\frac{1+\sigma}{\sigma} \cdot \frac{I}{Q_{M}}(\mathrm{II} \cdot \mathrm{AI})
$$

By substituting (II.AI) into (3.AI) we obtain (5.AI). That means that the utilisation of capacity changes with variations in investment.

When there is excess capacity, an increase in investment will produce an increase in output and in the utilisation of capacity such as to hold the investment-to-output-ratio equal to the share of profits even without overhead labour or assuming excess capacity. The consequence of assuming full capacity is that (3.AI) becomes:

$$
\Pi=\frac{I}{Q_{M}} \text { (I.I) }
$$

A higher accumulation of capital increases investment to the full employment output as well as the profit share. That is why in the Neo-Keynesian tradition a higher rate of accumulation goes along with inflation. 


\section{I.2 The Wage Profit Frontier}

From the Appendix I we get:

$$
\frac{w}{p}=\rho \cdot\left(1-\frac{r \cdot v}{u}\right)(\mathrm{I} 2 . \mathrm{AI})
$$

In the models of Kaldor and Robinson the utilisation of capacity is assumed to be at its full employment level in the long run. The equation under the Neo-Keynesian assumption becomes:

$$
\frac{w}{p}=\rho \cdot(1-r \cdot v)(\mathrm{I} 3 \cdot \mathrm{AI})
$$

There is an inverse relationship between the real wage rate and the rate of profit. A higher rate of profit is only possible at the expense of labour incomes. In the Marxian tradition the real wage is fixed by historical-social factors at its subsistence level and determines the maximum rate of profit.

\section{The Post-Keynesian Kaleckian Model}

For his theory of prices Kalecki assumes that "the marginal cost is horizontal over a rather long range of output and starts rising only when full capacity is approached" (Kalecki I966: 50) (see figure I). ${ }^{2}$

Figure I: Constant Marginal Cost Until Full Capacity Output

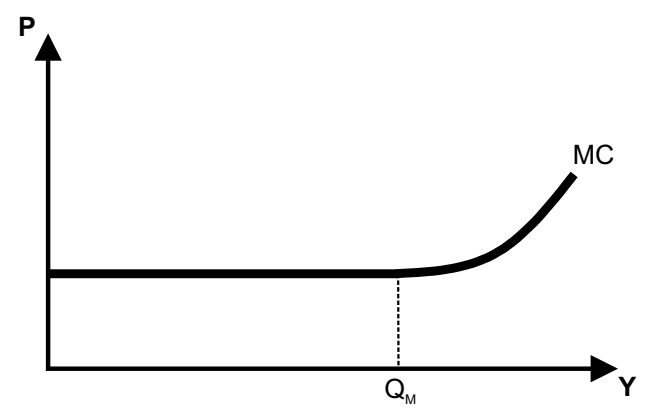

Therefore, with a given degree of monopolisation, raw material prices, nominal wages and the prices of the final product remain unchanged. Fluctuations in price do not depend on fluctuations in output when marginal costs are constant. For stable unit prime cost price fluctuations depend just on changes in the degree of monopolisation and not on

2 This assumption was made as early as 1938 by Dunlop (1938) and Tarshis (1938) and followed by many others, e.g. Blinder (1998), Eiteman/Guthrie (1952), all of them supporting the notion that marginal production costs are constant over the relevant output range. 
fluctuations in output or employment. The degree of monopolisation is prone to change alongside movements in the process of concentration in industries, sales promotion and the power of trade unions. However the explanation of these variables goes beyond the scope of this paper. ${ }^{3}$

For Kalecki, capitalist societies are characterised by holding excess capacity throughout almost the entire business cycle. Hence, the utilisation of capacity is not at its full employment level and it varies over the time in response to changes in demand.

As a consequence, the profit share remains constant under the assumptions underlying the simplest model. A higher accumulation of capital will produce an increase in production and capacity utilisation.

From (II.AI) we get:

$$
\begin{gathered}
u=\frac{v \cdot g}{\Pi} \quad \text { (2.I) } \\
\text { with } g=\frac{I}{K} \text { and } v=\frac{K}{Q_{M}}
\end{gathered}
$$

Thus without overhead labour the share of profits is given by a constant mark-up. The higher the mark-up, the higher the profit share and the lower production, employment and capacity utilisation. This also implies that for a given accumulation of capital, the higher the mark-up, the lower output and capacity utilisation in order to hold the investment-to-output-ratio equal to the share of profits.

At this stage, it is clear that the only way to increase the share of profits and the investment-to-output-ratio is to increase the mark-up.

\section{I The Paradox of Costs}

We saw that in the Neo-Keynesian model one of the consequences of assuming full employment is the emergence of a wage-profit-frontier (along which there is an inverse relationship between real wage and the rate of profit). In the Post-Keynesian framework $u$ is variable. The equation (I2.AI) is now:

$$
\begin{gathered}
\frac{w}{p}=\rho \cdot\left(1-\frac{g \cdot v}{u}\right)(2.2) \rightarrow u=\frac{\rho}{\rho-\frac{w}{p}} \cdot(g \cdot v) \quad(2.3) \\
\text { with } \frac{\partial u}{\partial \frac{w}{p}}>0
\end{gathered}
$$

For a given accumulation of capital, the higher the real wage, the higher the utilisation of capacity and output. The neoclassical negative relationship between real wages and output is reversed: a higher level of real wages creates more employment and output. 
In the long run, if accumulation of capital hinges on capacity utilisation as for example in the following equation, we obtain the following dynamic equation ( $a$ and $\alpha$ are both constant):

$$
g_{t}=a+\alpha \cdot u_{t-1}(2.4)
$$

The higher the capacity utilisation, the higher the rate of profit and the accumulation of capital. Therefore an increase in real wages produces a higher utilisation of capacity and accumulation of capital and employment.

\section{Minsky's Determination of Prices}

To analyse how prices are formed, Minsky assumes that labour is fully employed to produce consumption or investment goods and that workers spend their wages on consumption goods.

$P_{C}$ is the price and $Q_{C}$ is the quantity of a representative consumer good. $W_{C}$ is the money wage rate in the production of consumer goods and $W_{I}$ the money wage rate in the production of investment goods. $N_{C}$ is employment in the consumer goods sector, $N_{I}$ is employment in the investment goods sector and $\Pi_{C}$ are profits in the consumer goods sector. The cost of overhead labour is not included in the model.

$$
\begin{gathered}
P_{C} \cdot Q_{C}=W_{C} \cdot N_{C}+W_{I} \cdot N_{I} \\
\Pi_{C}=P_{C} \cdot Q_{C}-W_{C} \cdot N_{C}=W_{I} \cdot N_{I}(3.2)
\end{gathered}
$$

Profits in the consumer goods sector equal wages in the investment goods sector. This result is also obtained by Kalecki in the Theory of Economic Dynamics:

"The capitalists in department III (consumer goods sector), after having sold to workers the amount of consumption goods corresponding to their wages, will still have left a surplus of consumption goods which will be the equivalent of their profits. These goods will be sold to the workers of department I and department II« (Kalecki 1954: 47).

Indeed, Minsky (1982: 88) obtained these equations from Kalecki (I97I). However as the determinants of profits, Kalecki assumed an elastic supply so that employment in the consumer goods sector increases with employment in the investment goods sector. ${ }^{4}$

The profit equation of the simple model led Minsky to his perspective of how prices are formed (Minsky 1986: 254):

$$
P_{C}=\frac{W_{C}}{A_{C}} \cdot\left(1+\frac{W_{I} \cdot N_{I}}{W_{C} \cdot N_{C}}\right)
$$

4 "The above argument is based on the assumption of elastic supply« (Kalecki 1966: 47). 
With $A_{C}=\frac{Q_{C}}{N_{C}}$ being the average productivity of labour in the production of consumer
goods. Minsky defined the mark-up $(\mu)$ as depending upon the financed demand for output (Minsky i986: 254):

$$
\mu=\left(\frac{W_{I} \cdot N_{I}}{W_{C} \cdot N_{C}}\right)(3.4)
$$

This supposition led him to believe that increases in investment and government spending lead to inflation through increasing mark-ups. ${ }^{5}$

The average level of consumption goods prices is endogenously determined in the model. Ceteris paribus, an increase in investment will positively affect consumption goods prices: »Investment [...] forces the surplus by affecting prices« (Minsky I986: I46).

Profits seem to have arisen from the determination of prices, which seems to be the source of validating firms' cash commitments: »Profits result from an excess of prices over unit labour and purchased input costs« (Minsky I978: I4). »[T] he price system must generate cash (profits, quasi-rents) « (Minsky 1986: I42). In our view investment does not affect prices, ${ }^{6}$ which are determined exogenously. ${ }^{7}$ Also, prices do not affect profits, ${ }^{8}$ which are determined by the flow of capitalists' expenditure, i.e. investment and capitalists' consumption out of profits. Given a determined level of investment demand, for any set of prices the level of obtainable profits remains constant and is determined by the financed aggregate investment. ${ }^{9}$

We consider the determination of prices as a dynamic mechanism through which the struggles between social classes for a bigger share of income and between industrial sectors for a higher share of profits are reflected in the economic system. We view mark-up pricing as the strategic allocation of full costs onto product prices over time. ${ }^{\text {IO }}$ Furthermore we consider the mark-up as the reflection of all economic and institutional forces influencing capitalists' ability to include a higher percentage of full costs in the prices of their products.

5 "In our economy the causal chain that leads to inflation starts with rising investment or government spending which leads to increases in mark-ups" (Minsky 1986: 256).

6 At least not instantaneously via mark-up but over time when capacity utilisation is reaching its maximum level, allowing firms to allocate strategically a higher percentage of full cost onto product prices. 7 If unit price cost is constant, prices only depend on the mark-up, which reflects the degree of monopolisation in the economy.

8 "[F]irms, considered as a whole, cannot increase their profits merely by raising prices. The share of profit is increased but the total profits remain equal to the flow of capitalists' expenditure" (Robinson 1969: I47).

9 If we start at full employment and investment increases, then it is clear that profit margins must increase (Skouras I975: 4).

IO "The full costs of products are determined by the firms that produce them [.] [...] [T]here is room for the strategic allocation of those costs« (Shapiro/Sawyer 2003: 23). 
The determination of prices establishes the working class's purchasing power in real terms. Increases in nominal wages throughout the economy raise profits in the consumer goods sector and reduce them in the investment goods sector, holding total profits at the level determined by financed investment demand. Decreases in consumption goods prices increase labour's purchasing power by increasing real wages throughout the economy and employment in the consumption goods sector.

\section{A Post-Keynesian Model}

We will start off with the same equations and assumptions used by Minsky to derive his price equation (3.3). However in the model presented in the following the price is not deterministically fixed by investment, demand and public deficit. We assume that increases in the demand for consumer goods do not affect the mark-up on labour costs. When faced with an increased demand for consumer goods, the firm reacts by increasing the production of consumer goods as long as there is excess capacity. ${ }^{\text {II }}$

As Kalecki assumed:

»[E]mployment and production of department III (consumer goods) will be pushed up to the point where the surplus of this production over what the workers of this department buy with their wages is equal to the wages of departments I and II" (Kalecki 1954: 47).

With a given price, it is employment and production which adjust to hold profits equal to investment. Additionally Skouras assumed that "the level of output and employment all crucially depend on the firms' pricing policy « (Skouras 1975: 3). Employment in the consumer goods sector depends on firms' price fixation, reflecting the relation of power that firms exert on the market, which determines the quantity exchanged. Ceteris paribus, a higher price means a lower quantity sold. Kalecki and Skouras seem to agree about the mechanism through which changes in demand affect employment and production under imperfect competition. The firm sets its price according to its market power; e.g. a price rise reduces demand less than proportional, increasing profits at the same time. Thus higher market power is translated into higher mark-ups and a lower quantity exchanged. However, Minsky supposed that the mark-up depends on the demand. »[M] ark-ups reflect the investment and government financing that takes place (Minsky 1986: 176). Furthermore, "prices in our accumulating economy are the carriers of profits" (Minsky 1986: 254). Therefore the mark-up carries the cash flows that validate firms' past debts. Therefore, when the markup decreases, firms' cash flows decline too. "[L]ower money wages and prices lead to lower profits." (Minsky 1986: 176) The mark-up in the consumer goods sector is determined by the economic conditions shaping the demand for consumer goods. 
On the contrary, a Kaleckian model would be used to determine the level of employment and output, given the level of prices and investment.

From the equation (3.3) and $A_{C}=Q_{C} / N_{C}$ we obtain the following result:

$$
Q_{C}=\frac{W_{I} \cdot N_{I}}{\left(P_{C}-\frac{W_{C}}{A_{C}}\right)}
$$

Given prices as determined exogenously, this equation is used to determine the level of demand for consumer goods and of employment in the consumer goods sector. Figure 2 represents the rectangular hyperbola resulting from equation (4.I), which plots the isoprofit curve for the consumer goods sector. Given a fixed level of investment, for any combination of prices and output of consumer goods along this curve, the consumer goods sector's profits remain constant. Figure 2 shows the effect of different levels of investment on prices and employment.

Figure 2: Shift in the Iso-profit Curve Due to Investment

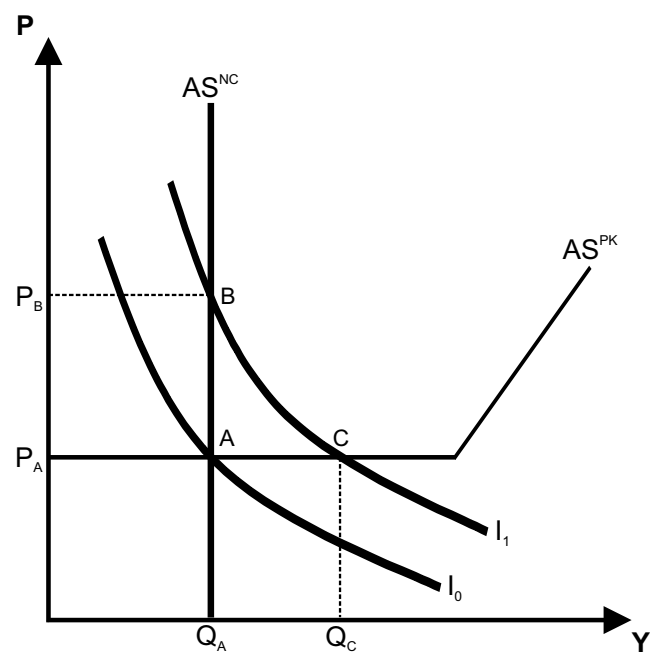

$B C$ represents a possible combination of price and output if the level of investment is $I_{1}$ instead of $I_{0}$.

In figure 2, $B$ would mean that a higher level of investment has not had any effect on production and employment in the consumer goods sector, which is due to an inelastic supply of consumer goods. The consumer goods sector's aggregate supply would in this case be totally inelastic in the short run (neoclassical aggregate supply $-A S^{N C}$ ). If $Q_{A}$ is the full employment level of the supply of consumer goods, a higher level of investment would not influence employment in the consumer goods sector and the only effect would be a higher mark-up per unit of output and therefore a higher share of capitalists in income. 
$C$ can only be reached if the supply of consumer goods is perfectly elastic in the short-run and if there are enough idle means of production or excess capacity to produce the demanded consumer goods without any influence on prices in the short-run (PostKeynesian aggregate supply $-A S^{P K}$ ).

\section{Government Deficit and Inflation}

The deficit is the excess of government spending over tax receipts. For Minsky the government deficit is one of the components of the consumer goods' mark-up.

"From the equation it is clear that the sum of wages in investment goods, the government deficit, and taxes on profits determine the mark-up on unit labour costs." (Minsky 1986: I48)

$$
P_{C}=\frac{W_{C}}{A_{C}} \cdot\left(1+\frac{W_{I} \cdot N_{I}}{W_{C} \cdot N_{C}}+\frac{G D_{F}-\Pi_{G}}{W_{C} \cdot N_{C}}+\frac{T_{\Pi} \cdot \Pi}{W_{C} \cdot N_{C}}\right)
$$

Being $G D_{F}$ the budget deficit, $\Pi_{G}$ the profits earned in producing for the government, $T_{\Pi}$ the tax rate on aggregate profits and $\Pi$ aggregate profits. When the components of the mark-up increase relative to the wage bill in the consumer goods sector, mark-up inflation is generated. Therefore, the government deficit not only affects aggregate profits but also relative prices through equation (5.I). Nevertheless employment and production in the consumer goods sector depend on the price of consumer goods.

In this model the government deficit does not affect prices but the production of consumer goods. This is due to the assumption of a totally elastic supply of consumer goods and therefore excess capacity.

$$
Q_{C}=\frac{\left(W_{I} \cdot N_{I}+G D_{F}-\Pi_{G}+T_{\Pi} \cdot \Pi\right)}{P_{C}-\frac{W_{C}}{A_{C}}}
$$

An increase in government deficit has the same effect on consumer goods production as an increase in investment, moving the iso-profit curve upwards. The upward move is correlated with increasing aggregate profits and employment in the consumer goods sector. The utilisation of capacity (output gap) is also higher (reduced) (see figure 3).

When the utilisation of capacity in the consumer goods sector reaches its maximum level, almost every product that can be produced is socially necessary and every unit of productive capital yields its optimum level in real terms.

Therefore the capitalists in the consumer goods sector will at this stage very likely choose to include a higher percentage of their full cost in the price, which increases their aggregate mark-up. The augmented profits in the consumer goods sector will positively influence the demand for investment goods, increasing the rate of capital accumulation and productive capacity. 
Figure 3: Shift in the Iso-profit Curve Due to Public Deficit

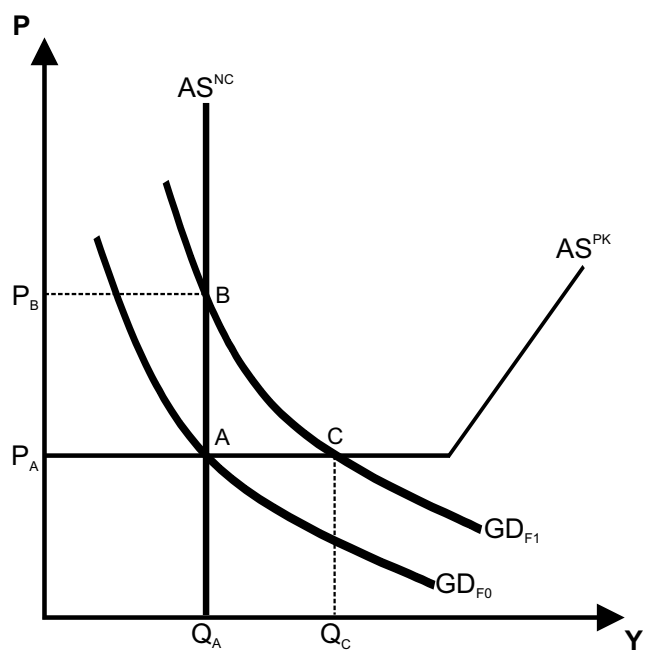

It is difficult to understand how an increase in public deficit would affect prices instantaneously in an environment where the rate of capital accumulation is growing faster than the public deficit and where the utilisation of capacity might be decreasing. On the other hand, if the rate of capital accumulation and along with it the rate of unemployment are decreasing, an increase in public deficit will sustain aggregate profits but might put inflationary pressure on consumer goods prices if the utilisation of capacity is reaching its full capacity level. The normal actuation of the government - stabilising aggregate profits - might cause inflation when the aggregate supply starts to behave in a neoclassical fashion. The persistence of inflation in times of high unemployment can not be explained by the traditional Phillips curve which proclaims a trade-off between inflation and unemployment.

If, due to inflationary expectations, monetary policy becomes restrictive and the Central Bank decides to increase short-term interest rates, spending could be cut but at the expense of reducing investment through increasing the financial cost of investment. If profitability is already low, the increase in interest rates may produce an undesirable much higher decrease in investment demand, therefore decreasing the economy's capacity of production and capacity utilisation.

Restrictive monetary policy has a decisive effect on economic activity. It alters the distribution of aggregate profits from non-financial corporations to financial corporations. As a result returns incline towards financial speculation and decrease the accumulation of capital and productive capacity. This process is not sustainable in the long run in terms of price stability and might lead to inflation persisting in times of high unemployment which is "a new thing of the past two decades" (Minsky 1986: 26I).

For the orthodox economist, interest rates are determined by the interaction of supply of and demand for credit. When governments run higher budget deficits, national 
savings decline, thereby decreasing credit supply and increasing short-term interest rates, which causes investment to fall. Expansionary fiscal policy is eventually depressive and therefore inefficient to promote and sustain full employment equilibrium. However, this assumption makes no sense on several grounds:

I. Public deficit increases aggregate profits and therefore firms' savings. Thus, in contrast to the orthodox belief public deficit increases national savings.

2. Fiscal policy is therefore an efficient way to step out of the recession. For example in I974 US investment was almost stagnant, the budget deficit was not sufficient (around 0.3 percent of GDP) to stabilise aggregate profits and firms' internal sources of funds were decreasing by approximately -3.6 percent. In 1975 the purchase of physical assets had decreased - due in part to diminished internal sources of funds - by almost eight percent, although the government ran a budget deficit of about five percent of GDP, a very significant increase which produced a 50 percent increase in firms' internal sources of funds. By 1976 investment had increased by almost 40 percent and the US had overcome the downswing (Minsky 1986: 27).

Minsky maintains that using the government deficit to stabilise aggregate profits has a cost in terms of inflation. He argues that this mark-up inflation is the result of economic policies designed to sustain aggregate profits via public deficit, while Saad-Filho (2002) finds no correlation between inflation and fiscal deficit in Brazil and Seccareccia/Sood (2000) have shown that deficit and inflation are not correlated.

According to Minsky, in today's economic structure deep depressions seem to be tied to the emergence of aggravated cyclical inflation. Although more rigorous empirical research is needed, Minsky's statements do not seem coherent with some empirical facts. The US deficit shifted from a surplus of I.4 percent of GDP in 2000 to a deficit of 3.6 percent of GDP in 2003 and in the euro zone the deficit moved from a surplus of o.I percent of GDP to a deficit of 2.7 percent of GDP. While for Minsky these developments in public deficit would cause aggravated inflation, US inflation has been stable around I.5 percent, half a percentage point lower than the euro zone's, even though Europe was running a much lower government deficit than the US. On the other hand the Federal Reserve intervention rate went down from 6.5 percent in $200 \mathrm{I}$ to one percent in June 2003. The quarterly average percentage of gross fixed capital formation was around eight percent between 2000 and 2005. However, in Europe the short-term interest rate has been reduced from 4.75 percent in 2001 to two percent in 2003 . The quarterly average percentage of gross fixed capital formation was about zero percent between 2000 and 2005 . In the US, the increase in productive capacity has been much higher than in the Euro-zone, which might have affected the price dynamics in both economic areas. 


\section{Conclusion}

Prices have always been a subject of research and controversy since the beginning of economic thought. The meaning and substance of price are rooted in the essence of the theoretical model in question. Some economists believe that prices move freely in response to the free movement of supply and demand, guaranteeing the full employment of resources. No economic agent has the power to force the free market out of the equilibrium path. An increase in prices is thought to bring about an increase in profits, which will induce a higher accumulation of capital, employment and capacity of production in the longrun. Post-Keynesian economists, however, find that excess capacity and prices represent the power of firms to increase its mark-up. An individual capitalist can increase its gross profit by increasing the mark-up. The curse of the capitalists as a class is that they cannot increase their aggregate profits by increasing the average mark-up or profit share. In addition, the exploitation of labour does not guarantee future profits for the capitalist class.

From (2.I) and (2.4) we get:

$$
r_{t}=a+\alpha \cdot v \cdot \frac{r_{t-1}}{\Pi_{t-1}}(\mathrm{C} . \mathrm{I})
$$

When accumulation depends exclusively on the utilisation of capacity, an increase in the exploitation of labour or a higher mark-up will have a negative effect on the rate of profit. Minsky's determination of prices assumes that a higher demand will bring about inflation (see [3.4] and [5.I]). Assuming no change in wages, an increase in the mark-up is due to an increase in the ratio of total employment to consumer goods sector employment.

When there is excess capacity in the consumer goods sector, an increase in investment, public deficit or exports increases the production of consumer goods and employment, keeping the employment ratio constant. When there is no excess capacity in the consumer goods sector, employment and production cannot increase in the short-run, creating inelasticities in the supply of consumer goods which will create inflationary pressure. All variables affecting the accumulation of capital or productive capacity and the ability to satisfy the demand are vital to understand to what extent the demand pull explanation of inflation comes into action.

High interest rates in particular have a significantly negative effect on the economic system, not only because they have a negative effect on the accumulation of productive capacity or because they represent a prominent financial cost for the firms putting pressure on prices and lowering the utilisation of capacity, but also because they shift liquidity towards social groups with a lower propensity to consume, which will again decrease the utilisation of capacity. High interest rates and lower than expected rate of profits might induce insufficient investment to sustain the level of aggregate demand.

In case of this scenario productive capacity and the ability to satisfy the effective demand decrease. Any counter-cyclical policies aiming to increase aggregate demand and economic activity might cause inflationary pressures if there is no parallel growth of productive capacity. 
Public deficit might have been correlated with inflation. On the other hand, inflation might have actually been the significant dynamic consequence of excessively high interest rates.

Neoclassical thought assumes the economic system as free and able to achieve the full employment of resources. Nevertheless, unemployment has been a characteristic feature of almost all modern capitalist societies and power has been accumulated by only a few privileged, which have the power to increase mark-ups and prices.

The internal contradiction within capitalist societies is that the egoistic, maximising, rational and competitive behaviour of individuals is not synchronized towards the growth and realisation of the system. These contradictive forces are prone to reduce real wages through class-struggle and increase prices through higher mark-ups, leading to depressive tendencies in employment, profits and capacity utilisation which are pushing the economic path away from the complete utilisation of capacity.

Lower real wages imply a lower utilisation of capacity (2.3) and employment in the short-run. Moreover, as long as investment depends exclusively on the utilisation of capacity, lower real wages will also have a depressive effect on the utilisation of capacity and employment in the long-run.

To achieve full employment, capitalist societies need a sound level of exogenous demand to generate a maximum level of profit in order to foster additional productive capacity.

The objective of any firm in a capitalist society is the realisation of profit. As shown above, however, in contrast to Minsky's thought, higher profits are not the necessary consequence of higher prices, nor can they be sustained without an adequate level of effective demand.

\section{Appendix I}

Using a one-sector model:

$$
p \cdot Q=w \cdot N+p \cdot I(\text { I.AI })
$$

As Minsky we will use a mark-up price function:

\section{The Profit Share}

$$
p=\frac{w}{\rho} \cdot(1+\sigma)(2 . \text { A }) \quad \text { being } \rho=\frac{Q}{N}
$$

$$
\Pi=\frac{p \cdot I}{p \cdot Q}=\frac{I}{Q}=\frac{I}{u \cdot Q_{M}} \text { (3.AI) }
$$

Where $u$ is defined as:

$$
u=\frac{Q}{Q_{M}}(4 . \mathrm{AI})
$$


Narciso Tuñez-Area: Does Public Deficit Mean Inflation?

$$
\Pi=1-\frac{w}{p} \cdot \frac{1}{\rho}=\frac{\sigma}{1+\sigma} \text { (5.AI) }
$$

The Demand for Labour

$$
p \cdot Q-p \cdot I=w \cdot N \quad(6 . \mathrm{AI})
$$

Dividing by $p$ we obtain:

$$
Q-I=\frac{w}{p} \cdot N \quad(7 \cdot \mathrm{AI})
$$

Dividing by $N$ we obtain:

$$
\begin{gathered}
\rho-\frac{I}{N}=\frac{w}{p} \rightarrow N=\frac{I}{\rho-\frac{w}{p}}(8 . \mathrm{AI}) \\
N=\frac{1+\sigma}{\sigma} \cdot \frac{I}{\rho} \quad \text { (9.AI) }
\end{gathered}
$$

\section{The Utilisation of Capacity}

Using (I.AI), (4.AI) and (8.AI):

Dividing by $p$ we obtain:

$$
p \cdot u \cdot Q_{M}=\frac{w \cdot I}{\rho-\frac{w}{p}}+p \cdot I \quad(\text { Iо.АI })
$$

$$
\begin{aligned}
u \cdot Q_{M}=\frac{w}{p} \cdot \frac{I}{\rho-\frac{w}{p}} \cdot I+I \rightarrow u \cdot Q_{M} & =\left(\frac{1}{\sigma}+1\right) \cdot I \rightarrow u=\frac{1+\sigma}{\sigma} \cdot \frac{I}{Q_{M}} \text { (II.AI) } \\
\rightarrow u & =\frac{I}{\Pi \cdot Q_{M}}
\end{aligned}
$$

If $u=1$ :

$$
\Pi=\frac{I}{Q_{M}}
$$

\section{The Wage Profit Frontier}

From (8.AI):

$$
\frac{w}{p}=\rho-\frac{I}{N} \rightarrow \frac{w}{p}=\rho \cdot\left(1-\frac{r \cdot v}{u}\right)(\text { I2.AI })
$$

If $u=1$ :

$$
\frac{w}{p}=\rho \cdot(1-r \cdot v) \quad(\mathrm{I} 3 \cdot \mathrm{AI})
$$

Equation (I3.AI) indicates the negative relationship between the real wage and the rate of profit. 


\section{References}

Arestis, Philip (2003): Aggregate Demand, Conflict, and Capacity in the Inflationary Process, in: The Levy Economics Institute of Bard College Working Paper, No. 391, Annandaleon-Hudson

Blinder, Alan S. (1998): Stop me before I inflate again: The Rules-versus-discretion Debate Revisited, Proceedings, Federal Reserve Bank of Chicago, pp. 502-508

Chevalier, Judith A./Scharfstein, David S. (1996): Capital Market Imperfections and Countercyclical Mark-ups. Theory and Evidence, in: American Economic Review, Vol. 86, No. 4, pp. 703-725

Dunlop, John T. (1938): The Movement of Real and Money Wages, in: Economic Journal, Vol. 48, No. 3, pp. 4I3-434

Eiteman, Wilfred J./Guthrie, Glenn E. (1952): The Shape of the Average Cost Curve, in: American Economic Review, Vol. 42, No. 5, pp. 832-838

Glyn, Andrew (1998): Employment Growth, Structural Change and Capital Accumulation, in: ESRC Centre for Business Research, University of Cambridge, Working Paper, No. 97

Iyoda, Mitsuhiko (2000): Mark-up Fluctuations in the Business Cycle. A Kaleckian View, Paper prepared for the $26^{\text {th }}$ General Conference of the International Association for Research in Income and Wealth, Krakow/Poland, 27 August to 2 September 2000

Kalecki, Michal (1954): Theory of Economic Dynamics, reprinted in: Osiatynski, Jerzy (ed.), The Collected Works of Michal Kalecki, Vol. 2, Oxford: Oxford University Press, I99I

Kalecki, Michal (1966): The Studies in the Theory of Business Cycles, 1933-1939, London: Basil Blackwell

Kalecki, Michal (1971): Selected Essays on the Dynamics of the Capitalist Economy 1933-1970, Cambridge: Cambridge University Press

Lavoie, Marc (1992): Foundations of Post-Keynesian Economic Analysis, Aldershot, UK: Edward Elgar

Minsky, Hyman P. (1978): The Financial Instability Hypothesis: A Restatement, in: Thames Papers on Political Economy, London: Thames Polytechnic

Minsky, Hyman P. (1982): Can »It« Happen Again? Essays on Instability and Finance, Armonk: M.E. Sharpe

Minsky, Hyman P. (1986): Stabilizing an Unstable Economy, New Haven: Yale University Press

Robinson, Joan (1969): The Economics of Imperfect Competition, $2^{\text {nd }}$ edition, London: Macmillan

Rowthorn, Robert E. (198I): Demand, Real Wages and Economic Growth, in: Thames Papers on Political Economy, London: Thames Polytechnic, pp. I-39

Rowthorn, Robert E. (I995): Capital Formation and Unemployment, in: Oxford Review of Economic Policy, Vol. I, No. II, pp. 26-39

Saad-Filho, Alfredo (2002): Inflation and Stabilization in Brazil. A Political Economy Analysis, in: Review of Radical Political Economics, Vol. 34, No. 2, pp. I09-I35 
Seccareccia, Mario/Sood, Atul (2000): Government Debt Monetization and Inflation: A Somewhat Jaundiced View, in: Bougrine, Hassan (ed.), The Economics of Public Spending: Debts, Deficits and Economic Performance, Cheltenham: Edward Elgar, pp. $122-34$

Shapiro, Nina/Sawyer, Malcolm (2003): Post Keynesian Price Theory, in: Journal of Post Keynesian Economics, Vol. 25, No. 3, pp. 355-365

Skouras, Thanos (1975): Government Activity and Private Profits, in: Thames Papers on Political Economy, London: Thames Polytechnic

Tarshis, Lorie (1938): Real Wages in the United States and Great Britain, in: Canadian Journal of Economics and Political Science, Vol. 4, No. 3, pp. 362-376

Wray, Randall (2000): Money and Inflation, Center for Full Employment and Price Stability Working Paper, No.I2 